EXPERIMENTAL STUDY

\title{
Growth hormone (GH) rebound rise following somatostatin infusion withdrawal: studies in dogs with the use of GH-releasing hormone and a GH-releasing peptide
}

\author{
Antonello E Rigamonti, Guido Cavallera, Sara Bonomo, Romano Deghenghi ${ }^{1}$, Vittorio Locatelli, Silvano G Cella \\ and Eugenio E Müller \\ Department of Medical Pharmacology, Chemotherapy and Toxicology, University of Milan, Milan, Italy, and ${ }^{1}$ Europeptides, Argenteuil, France \\ (Correspondence should be addressed to Eugenio E Müller; Department of Medical Pharmacology, Chemotherapy and Toxicology, University of Milan, \\ via Vanvitelli 32, 20129 Milan, Italy; Email: eugenio.muller@unimi.it)
}

\begin{abstract}
Objective: Evidence has been presented that in both animals and humans the rebound secretion of growth hormone $(\mathrm{GH})$ following withdrawal of an infusion of somatostatin (SS) is due to the functional activation of the hypothalamic GH-releasing hormone (GHRH) neurons of the recipient organism. Based on this premise, this study has sought to assess the existence of functional interactions between endogenous GHRH released by a SS infusion withdrawal (SSIW) and growth hormone-releasing peptides (GHRPs), a class of compounds allegedly acting via GHRH.

Methods: Five young dogs ( 3 to 4 years old, 2 male and 3 female) were administered, on different occasions, three consecutive intravenous boli of physiological saline $(0.1 \mathrm{ml} / \mathrm{kg})$, or GHRH $(2 \mu \mathrm{g} / \mathrm{kg})$, or EP92632 $(125 \mu \mathrm{g} / \mathrm{kg})$, a GHRP compound, or GHRH plus EP92632 at the end of three cycles of 1-h SS infusions $(8 \mu \mathrm{g} /(\mathrm{kg} \times \mathrm{h}))$ or during a 6 -h infusion of saline.

Results: Under saline infusion (SALI), plasma GH levels were unaltered, whereas each SSIW cycle was followed by similar GH secretory episodes. Administration of the first GHRH bolus under SALI induced a rise in plasma GH concentrations slightly higher than that induced by the first cycle of SSIW, but the GH response to the second and third GHRH boli was similar to that after SSIW. Following SSIW, the response to the first bolus of GHRH was higher than that during SALI, but the second and third cycles of SSIW induced GH responses similar to those evoked by the GHRH bolus. During SALI, administration of the first bolus of EP92632 induced a rise in plasma GH which was higher than that induced by the first GHRH bolus, the second bolus elicited a GH peak of lesser amplitude and there was a partial restoration of the GH response to the third peptide bolus. SSIW strikingly enhanced the GH release to the first EP92632 bolus, a pattern also present, although to a lesser extent, with the second and third cycles of SSIW. Under SALI, combined administration of GHRH and EP92632 had a synergistic effect on GH release, but a progressive reduction was present in the GH response to the second and third GHRH plus EP92632 boli. SSIW increased only weakly the GH response to the first co-administration of the peptides over that present after administration of EP92632 alone, and did not induce a GH response higher than that present during SALI when the second bolus of the peptides was administered; after the third SSIW a GH rise higher than that present during SALI was elicited by the combined administration of the peptides.

Conclusions: (i) the uniformity of the GH rebound responses to multiple cycles of SSIW may indicate that the latter activate a physiological mechanism which mimics that normally controlling GH pulse generation; (ii) EP92632 elicits, under our experimental conditions, a plasma GH rise higher than that induced by GHRH; (iii) SSIW enhances the GH response to EP92639 alone, to an extent reminiscent of that following combined administration of GHRH and EP92632. This pattern reinforces the view that SSIW elicits release of endogenous GHRH, and infers that the GHRP challenge after SSIW may be exploited in humans to distinguish between healthy and GH-deficient adults.
\end{abstract}

European Journal of Endocrinology 145 635-644

\section{Introduction}

A great many studies in animals and humans have provided evidence that somatostatin (SS) and growth hormone-releasing hormone (GHRH) are essential regulators of the secretion of growth hormone $(\mathrm{GH})$, and that hypothalamic SS tone dictates the pituitary responsiveness to repeated GHRH challenges (1-4). The GH secretory burst generated appears to be important in enhancing SS release, particularly during 
the trough period encountered in spontaneous $\mathrm{GH}$ secretory studies (negative GH auto-feedback) (5-6).

New complexity to our understanding of the neuroregulation of GH has been added by the development of a new class of peptides, the GH-releasing peptides (GHRPs) (7-11). They are potent GH releasers (12), act via specific receptor sites in both the hypothalamus and the pituitary (13-15) (divorced from GHRH receptor sites (16)) and for which an endogenous ligand, Grelin, has recently been identified (17-19). Several lines of evidence have indicated that in vivo and in vitro $\mathrm{GH}$ responsiveness to GHRPs is dependent on GHRH function $(6,12)$, whereas the functional interactions of SS with GHRPs have not been so extensively studied and appear more elusive. Somatostatin could inhibit GH response to GHRP by a hypothalamic (20) as well as a pituitary action (21, 22), and SS and GHRPs could act at either site as mutual functional antagonists $(7,23)$.

In recent years, studies in animals and humans have provided evidence that the rebound GH rise which follows withdrawal of an infusion of SS is due, at least in part, to the functional activation of GHRH neurons of the recipient organism (24-29). Thus, SS infusion withdrawal (SSIW) may represent a test to probe, inferentially, endogenous GHRH function, and may provide a potential tool in the diagnosis of growth disorders due to GH hyposecretory states (30) or to assess the declining GHRH function in ageing (29).

The rebound GH rise which follows SSIW could be magnified by the administration before SS withdrawal of GHRH $(27,28,31)$, implying that the SSIW approach might also be exploited to investigate in vivo the functional interaction between endogenous GHRH and GHRPs.

With this in mind, we studied the functional interactions between endogenous GHRH and GHRPs in the dog, a species which behaves like humans in most aspects of GH neuroregulation (32). Dogs were exposed to three consecutive SSIW cycles and were given at the end of each cycle GHRH, a GHRP peptide, or a combination of both; the timing and extent of the rebound $\mathrm{GH}$ rise were investigated.

\section{Materials and methods}

\section{Animals}

Five young well-trained beagle dogs (3-4 years old, 2 male and 3 female), weighing between $8-15 \mathrm{~kg}$, were used. They were exercised routinely and were fed normal dry food (Diete Standard, Charles River, Calco, Italy) once a day at $1600 \mathrm{~h}$, with water available ad libitum. They were on a 12-h light:12-h darkness regimen, with lights on at $0700 \mathrm{~h}$. At the beginning of the study, body weights of the dogs were stable and they had no observable diseases. All experiments were carried out in conscious animals. Before the experiments, animals were kept at rest in the laboratory for at least $1 \mathrm{~h}$.

Experiments on each dog were scheduled in a randomized order, at least 1 week apart, with continued training.

All the experiments were performed in accordance with protocols previously authorized by the Committee on Animal Care and Use of the University of Milan.

\section{Study design}

Following an overnight fast, two indwelling intravenous cannulae were inserted in the forearms at $0830 \mathrm{~h}\left(\mathrm{t}_{-30}\right)$. One cannula was used for slow intravenous infusion of saline or SS (see below), which was commenced at $t_{0}$, and the other for bolus administration of saline or compounds and for the collection of blood samples. Two groups of studies were performed.

Saline infusion The aim of these studies was to determine the effect on $\mathrm{GH}$ release of three consecutive administrations of saline, GHRH, EP92632 (Ala-His-D2Me-Trp-Ala-Trp-D-Phe-Lys- $\mathrm{NH}_{2}$ ), a member of the GHRP family, or GHRH plus EP92632 during a continuous 6-h saline infusion (SALI). The present unavailability of hexarelin (9) dictated the use of a new GHRP, EP92632, which has a lower efficacy than but a similar potency to hexarelin $\left(\mathrm{E}_{\max }=32 \mathrm{ng} / \mathrm{ml}\right.$ and $\mathrm{ED}_{50}=145 \mu \mathrm{g} / \mathrm{kg}$ vs $\mathrm{E}_{\max }=287 \mathrm{ng} / \mathrm{ml}$ and $\mathrm{ED}_{50}=$ $169 \mu \mathrm{g} / \mathrm{kg}$ for EP92632 and hexarelin respectively; A E Rigamonti, unpublished results). Saline $(4 \mathrm{ml} / \mathrm{h})$ was infused intravenously from $t_{-30}$ to $t_{360}$, and a bolus of saline $(0.1 \mathrm{ml} / \mathrm{kg})$, GHRH $(2 \mu \mathrm{g} / \mathrm{kg}$; Geref, Serono,

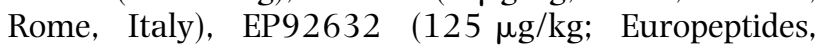
Argenteuil, France) or GHRH plus EP92632 was administered intravenously at $t_{60}, t_{180}$ and $t_{360}$. Blood samples for measurement of plasma GH concentrations were collected at $t_{-30}$, and $t_{0}$, and then at 15- to 30min intervals up to $360 \mathrm{~min}$.

Somatostatin infusion The aim of these studies was to determine the effects of three SS infusion withdrawals (SSIWs), consecutively performed, on the GH response to saline, GHRH, EP92632 or GHRH plus EP92632. Somatostatin $(8 \mu \mathrm{g} /(\mathrm{kg} \times \mathrm{h}))$ was infused intravenously for $60 \mathrm{~min}$, from $t_{0}$ to $t_{60}$, from $t_{120}$ to $t_{180}$ and from $t_{240}$ to $t_{360}$. At the termination of each SS infusion it was replaced by an infusion of saline, and a bolus injection of saline, GHRH, EP92632 or GHRH plus EP92632 was delivered, according to the above reported schedule. Blood samples for measurement of plasma GH were collected at $t_{-30}$ and at 30-min intervals during SS infusion and at 15-min intervals during SALI up to $360 \mathrm{~min}$. 


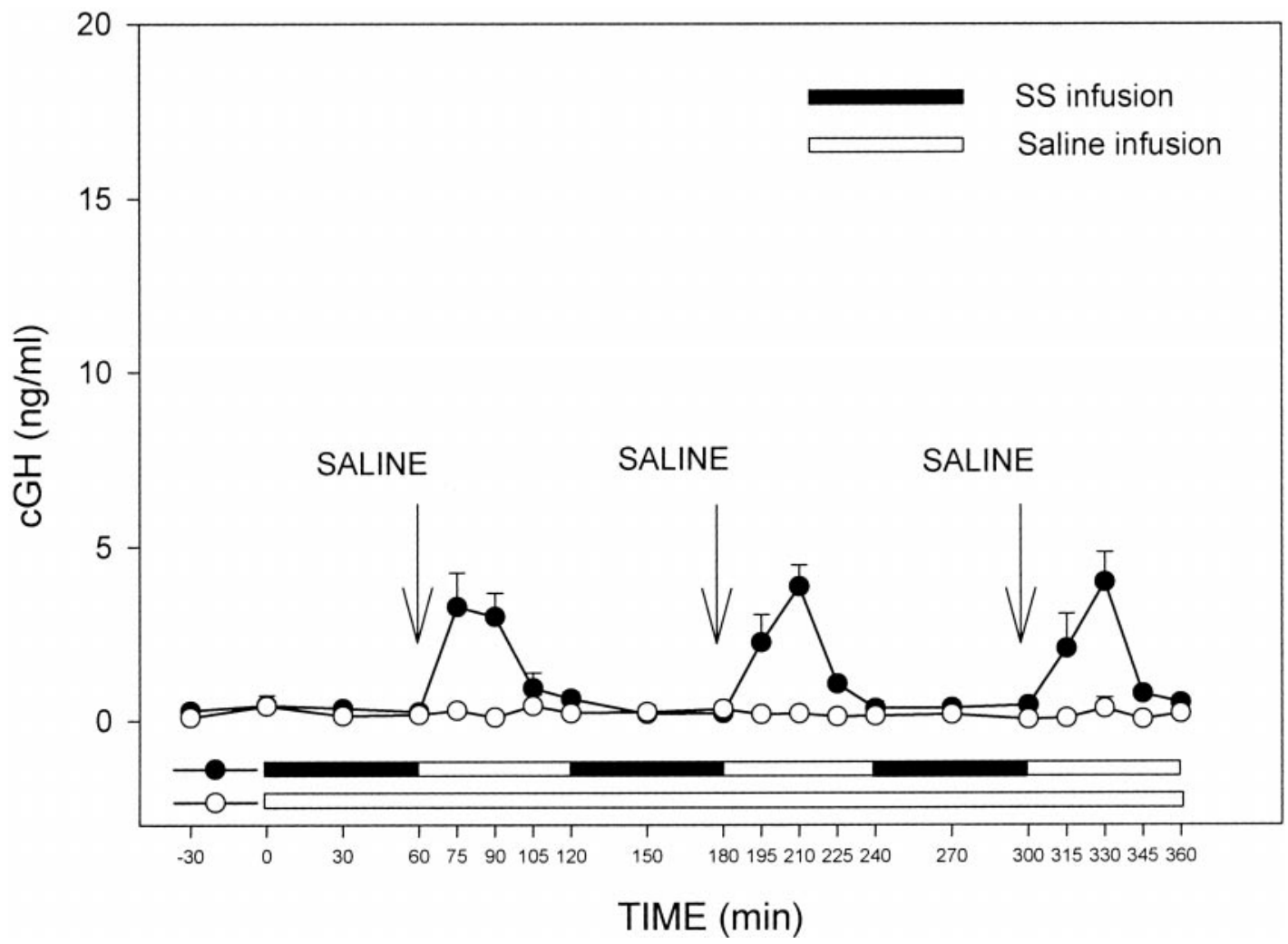

Figure 1 Plasma GH concentration profiles (means \pm S.E.M., $\mathrm{ng} / \mathrm{ml}$ ) from 5 dogs administered three consecutive boli of saline $(0.1 \mathrm{ml} / \mathrm{kg})$ during a continuous 6 -h saline infusion $(O)$ or three 1 -h cycles of SS infusion alternated with saline infusions of the same duration $(\bullet)$. Arrows indicate times of bolus injections. Bars indicate timing and duration of infusion (open bars, saline; solid bars, SS). The same description applies to Figs 2-4. Please note the different scales of GH values in the ordinates.

\section{GH radioimmunoassay}

Blood samples were collected in tubes containing $0.15 \mathrm{~mol} / \mathrm{l}$ EDTA and immediately chilled. Plasma was frozen until assayed for canine $\mathrm{GH}(\mathrm{cGH})$ by a double-antibody RIA. Highly purified cGH (Pituitary Hormones and Antisera Center, Torrance, CA, USA), obtained together with the specific antibody anti-cGH through the courtesy of Dr A F Parlow, was used for iodination and as a standard. The sensitivity of the assay was $0.39 \mathrm{ng} / \mathrm{ml}$. The intra-assay coefficients of variation were 3.8 and $4.1 \%$ at concentrations of 12.5 and $3.1 \mathrm{ng} / \mathrm{ml}$ respectively. To avoid possible interassay variation, all samples of a given experiment were assayed in a single RIA.

\section{Statistical analysis}

GH values were expressed either as absolute mean \pm S.E.M. values $(\mathrm{ng} / \mathrm{ml})$ (see Figs. $1-4)$ or as mean \pm S.E.M. area under the plasma concentration vs time curve (AUC $_{60-120 ; ~ S A L I} ; \mathrm{AUC}_{180-240 ;}$ SALI AUC $_{300-360 ; ~ S A L I}$ for saline infusion studies; AUC $_{60-120 ;}$ ssiw; AUC $_{180-240}$ ssIw; $\mathrm{AUC}_{300-360 ;}$ ssIw for $\mathrm{SS}$ infusion withdrawal studies; $\mathrm{ng} / \mathrm{ml} / \mathrm{min})$, calculated by the trapezoidal integration method (see Results and Table 1).

Since no differences in hormone levels between male and female dogs were observed in the different experimental conditions as was the case in other studies (9), the data were pooled.

Statistical evaluation of differences in absolute $\mathrm{GH}$ concentrations and mean values of AUCs among the different experimental conditions were performed by the Student-Newman-Keuls test, preceded by one-way ANOVA. $P<0.05$ was taken to be statistically significant.

\section{Results}

Profiles of mean plasma GH concentrations during the intravenous infusion of saline or SS, and bolus administration of saline or the compounds under study are shown in Figs. 1-4.

Table 1 depicts schematically the extent of the GH responses to three cycles of SSIW or during SALI after application of GH secretagogs. In spite of the variability of standard errors of AUCs (Table 1), the overall results obtained are sound. 


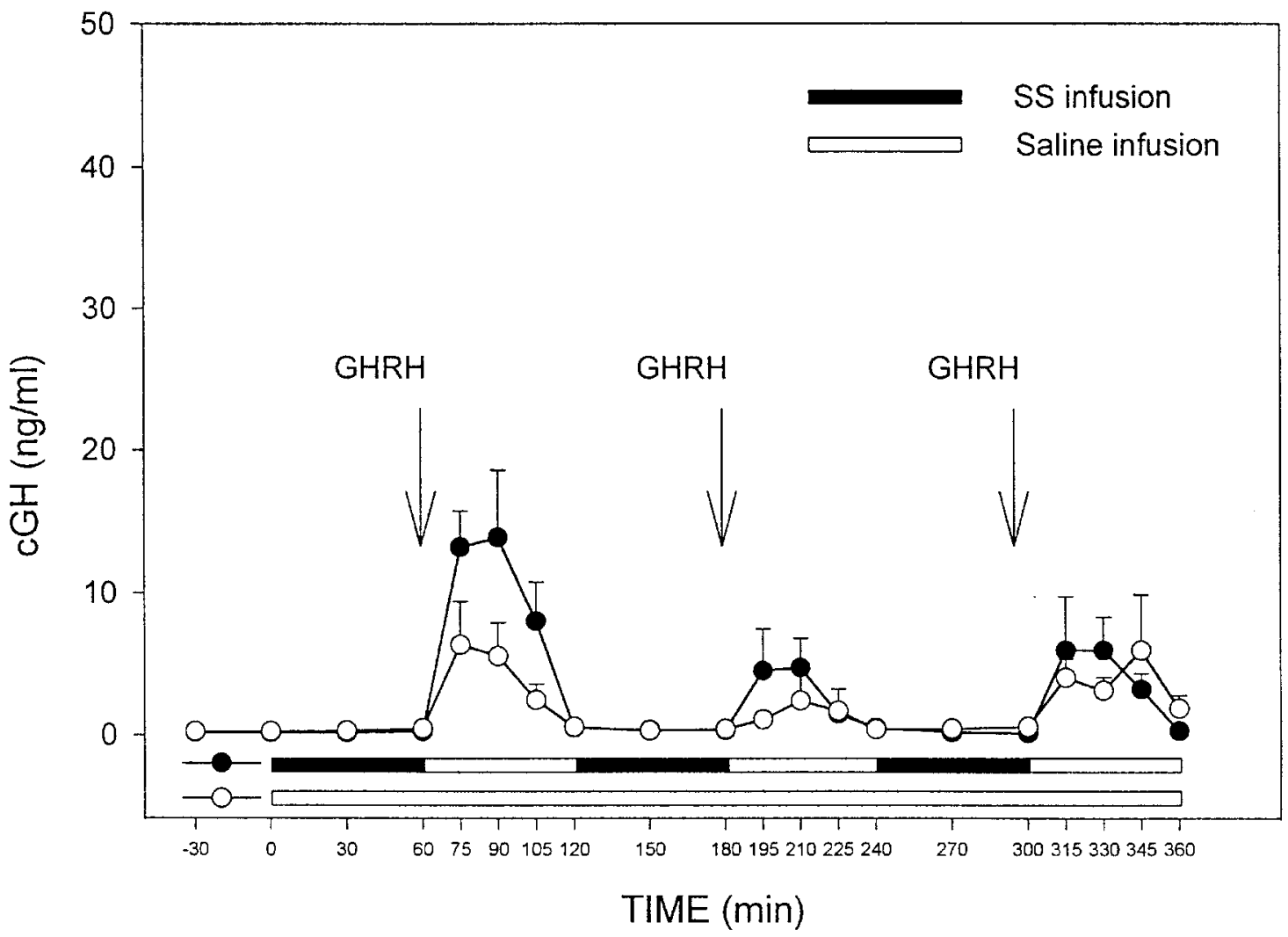

Figure 2 Plasma GH concentration profiles (means \pm S.E.M., $\mathrm{ng} / \mathrm{ml}$ ) from 5 dogs administered three consecutive boli of GHRH (2 $\mu \mathrm{g} / \mathrm{kg}$ iv).

Table 1 Areas under the curve (AUC) of plasma GH concentrations versus time (means \pm S.E.M. $\mathrm{ng} / \mathrm{ml} / \mathrm{min}$ ) from 5 dogs administered three consecutive boli of saline $(0.1 \mathrm{ml} / \mathrm{kg}), \mathrm{GHRH}(2 \mu \mathrm{g} / \mathrm{kg}$ iv), EP92632 (GHRP) $(125 \mu \mathrm{g} / \mathrm{kg}$ iv), and GHRH plus EP92632, during a continuous 6-h saline infusion or three 1-h cycles of SS infusion alternated with saline infusions of the same duration.

\begin{tabular}{cccc}
\hline & AUC $_{\mathbf{6 0 - 1 2 0}}$ & AUC $_{\mathbf{1 8 0 - 2 4 0}}$ & AUC $_{\mathbf{3 0 0 - 3 6 0}}$ \\
\hline Saline & & & \\
SALI & $14.9 \pm 8.6$ & $10.9 \pm 6.2$ & $8.4 \pm 5.5$ \\
SSIW & $114.5 \pm 14.4^{\mathrm{a}}$ & $111.7 \pm 10.8^{\mathrm{a}}$ & $108.5 \pm 12.1^{\mathrm{a}}$ \\
GHRH & & $81.7 \pm 59.5^{\mathrm{b}}$ & $213.2 \pm 84.9^{\mathrm{b}}$ \\
SALI & $222.4 \pm 98.2^{\mathrm{b}}$ & $165.8 \pm 73.9$ & $228.7 \pm 93.3$ \\
SSIW & $532.1 \pm 100.2^{\mathrm{a}}$ & & \\
GHRP & & $418.0 \pm 105.2^{\mathrm{d}}$ & $580.3 \pm 119.1$ \\
SALI & $940.6 \pm 136.9^{\mathrm{b}, \mathrm{c}}$ & $736.4 \pm 118.7^{\mathrm{a}}$ & $890.5 \pm 70.8^{\mathrm{a}}$ \\
SSIW & $1790.5 \pm 162.7^{\mathrm{a}}$ & & \\
GHRH+GHRP & & & \\
SALI & $2363.3 \pm 339.8^{\mathrm{b}, \mathrm{c}, \mathrm{e}}$ & $2210.9 \pm 151.6^{\mathrm{b}, \mathrm{c}, \mathrm{e}, \mathrm{f}}$ & $1353.8 \pm 248.4^{\mathrm{b}, \mathrm{c}, \mathrm{e}, \mathrm{g}}$ \\
SSIW & $2946.0 \pm 280.0^{\mathrm{h}, \mathrm{i}}$ & $1934.3 \pm 303.8^{\mathrm{i}}$ & $2378.1 \pm 534.0^{\mathrm{a}, \mathrm{i}}$ \\
\hline
\end{tabular}

a $P<0.01$ vs the respective AUC value (in the same cycle and with the same bolus injection) during saline infusion; ${ }^{b} P<0.01$ vs the AUC value (in the same cycle) during saline infusion and saline bolus injection; ${ }^{c} P<0.01$ vs the AUC value during saline infusion and $\mathrm{GHRH}$ bolus injection; ${ }^{d} P<0.01$ vs the $A C_{60-120}$ value during saline infusion and GHRP bolus injection; ${ }^{e} P<0.01$ vs the AUC value during saline infusion and GHRP bolus injection; ${ }^{f} P<0.01$ vs the $A \mathrm{C}_{60-120}$ value during saline infusion and $\mathrm{GHRH}$ plus GHRP bolus injection; ${ }^{9} P<0.01$ vs the $A U C_{180-240}$ value during saline infusion and GHRH plus GHRP bolus injection; ${ }^{h} P<0.05$ vs the respective AUC value during saline infusion; ${ }^{i} P<0.01$ vs the respective AUC value during SS infusion and GHRP bolus injection. 


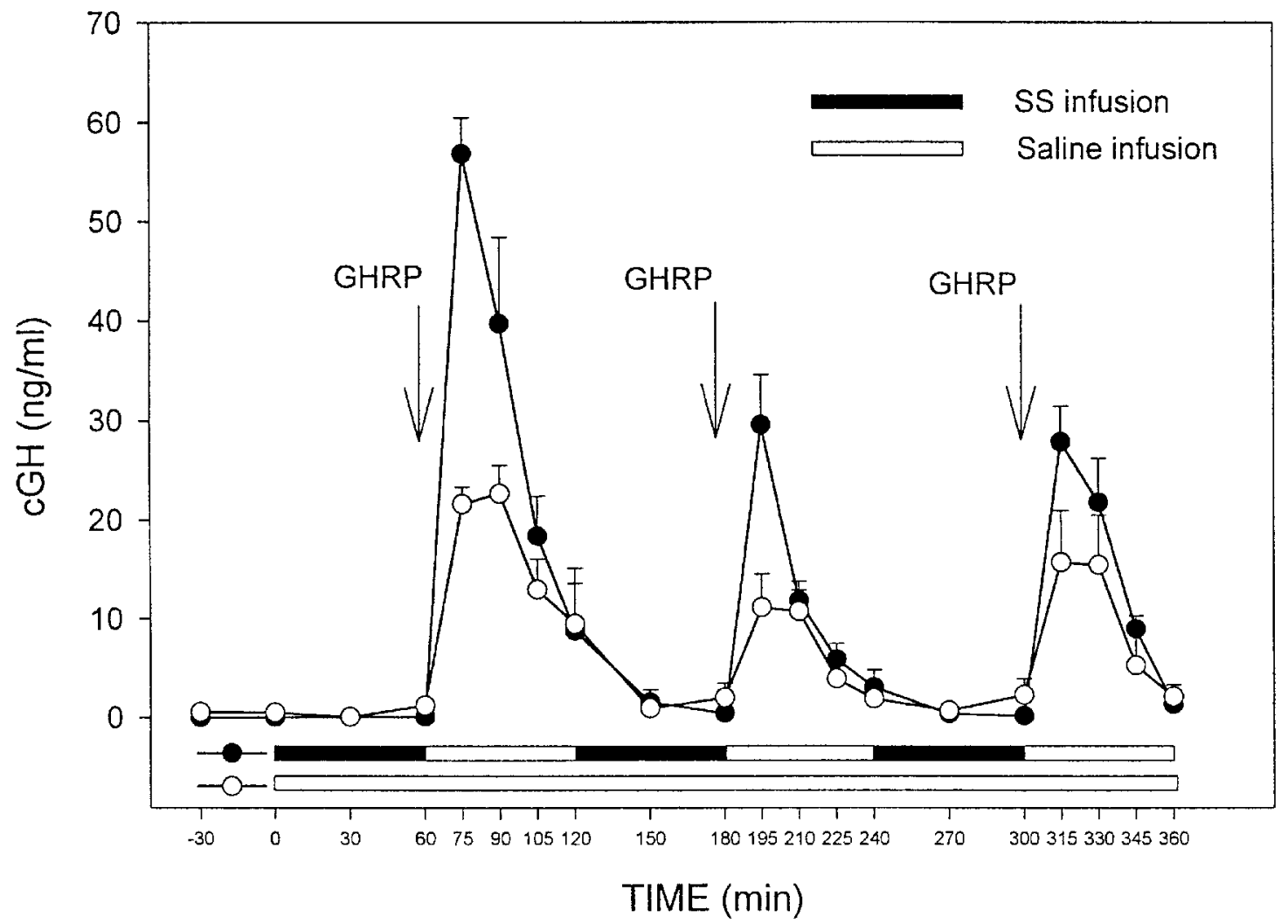

Figure 3 Plasma GH concentration profiles (means \pm S.E.M., $\mathrm{ng} / \mathrm{ml}$ ) from 5 dogs administered three consecutive boli of EP92632 (GHRP; $125 \mu \mathrm{g} / \mathrm{kg}$ iv).

The first SSIW, concomitant with the bolus injection of saline, elicited a clear-cut plasma GH rise, whereas during SALI the same bolus injection failed to increase plasma $\mathrm{GH}$ titers $\left(\mathrm{AUC}_{60-120 ;}\right.$ SsIW $=114.5 \pm 14.4 \mathrm{ng} /$ $\mathrm{ml} / \mathrm{min}$ vs $\quad \mathrm{AUC}_{60-120 ;}$ SALI $=14.9 \pm 8.6 \mathrm{ng} / \mathrm{ml} / \mathrm{min}$, $P<0.01)$. Similar significant $\mathrm{GH}$ increments were observed after the second and third SSIWs $\left(\mathrm{AUC}_{180-240}\right.$; ssiw $=111.7 \pm 10.8 \mathrm{ng} / \mathrm{ml} / \mathrm{min} \quad$ vs $\quad \mathrm{AUC}_{180-240 ;}$ SALI $=10.9 \pm 6.2 \mathrm{ng} / \mathrm{ml} / \mathrm{min}, P<0.01 ; \mathrm{AUC}_{300-360 ;}$ ssIW $=$ $108.5 \pm 12.1 \mathrm{ng} / \mathrm{ml} / \mathrm{min} \quad$ vs $\quad \mathrm{AUC}_{300-360 ;} \mathrm{SAL}=8.4 \pm$ $5.5 \mathrm{ng} / \mathrm{ml} / \mathrm{min}, P<0.01)$. No statistically significant differences were found between the plasma GH rebound rises after each SSIW $(P=$ NS) (Fig. 1; Table 1).

No spontaneous GH peak was observed during 6-h SALI after administration of saline boli, a finding in agreement with previous studies $(33,34)$, since the experiments were performed at times unfavorable for spontaneous generation of GH peaks (35).

Intravenous administration of the first GHRH bolus during SALI induced a rise in plasma GH concentrations higher than that elicited by the bolus injection of saline $\left(\mathrm{AUC}_{60-120 ;}\right.$ SALI $=222.4 \pm 98.2 \mathrm{ng} / \mathrm{ml} / \mathrm{min}$ vs AUC $_{60-120 ;}$ SALI after saline bolus; $P<0.01$ ). Under the same experimental conditions, the second GHRH bolus elicited a lower $\mathrm{GH}$ response $\left(\mathrm{AUC}_{180-240}\right.$; SALI $=$ $81.7 \pm 59.5 \mathrm{ng} / \mathrm{ml} / \mathrm{min}$ vs $\mathrm{AUC}_{60-120 ;}$ SALI,$P<0.01$ ), while the amplitude of the third GHRH-evoked GH response was intermediate between the extent of the first and second GHRH boli $\left(\mathrm{AUC}_{300-360 ;}\right.$; SALI $=213.2 \pm$ $84.9 \mathrm{ng} / \mathrm{ml} / \mathrm{min}$, vs $\mathrm{AUC}_{60-120}$; SALI,$P=\mathrm{NS}$ ).

SSIW induced a marked increase in the GH response to GHRH $\left(\mathrm{AUC}_{60-120: \mathrm{SSIW}}=532.1 \pm 100.2 \mathrm{ng} / \mathrm{ml} /\right.$ min vs $\mathrm{AUC}_{60-120}$; SALI, $P<0.01$ ). In contrast, the second and third SSIWs did not increase the second and third plasma GH responses to GHRH bolus with respect to those occurring during SALI $\left(\mathrm{AUC}_{180-240}\right.$; SSIW $=$ $165.8 \pm 73.9 \mathrm{ng} / \mathrm{ml} / \mathrm{min}$ vs $\mathrm{AUC}_{180-240 ;} \mathrm{SAL}, P=\mathrm{NS}$; $\mathrm{AUC}_{300-360: ~} \mathrm{sSIW}=228.7 \pm 93.3 \mathrm{ng} / \mathrm{ml} / \mathrm{min}$ vs $\mathrm{AUC}_{300-360}$; SALI $P=$ NS) (Fig. 2; Table 1).

EP92632, administered during SALI, induced a rise in plasma GH concentrations which was higher than those occurring after saline or GHRH bolus ( $\mathrm{AUC}_{60-120}$; sALI $=940.6 \pm 136.9 \mathrm{ng} / \mathrm{ml} / \mathrm{min}$ vs $\mathrm{AUC}_{60-120 ;}$;ALI after saline bolus, $P<0.01$, and vs $\mathrm{AUC}_{60-120 \text {; SALI }}$ after GHRH bolus, $P<0.01$ ). The second bolus of the peptide was followed by a $\mathrm{GH}$ peak of lesser amplitude $\quad\left(\mathrm{AUC}_{180-240 ;}\right.$ SALI $=418.0 \pm 105.2 \mathrm{ng} / \mathrm{ml} /$ min vs $\mathrm{AUC}_{60-120 ;}$ SALI, $P<0.01$ ), whereas there was a partial restoration of the $\mathrm{GH}$ response to the third EP92632 bolus which, however, did not reach statistical significance compared with the response to the second bolus $\left(\mathrm{AUC}_{300-360 ;} \mathrm{SALI}=580.3 \pm 119.1 \mathrm{ng} / \mathrm{ml} / \mathrm{min}\right.$ 


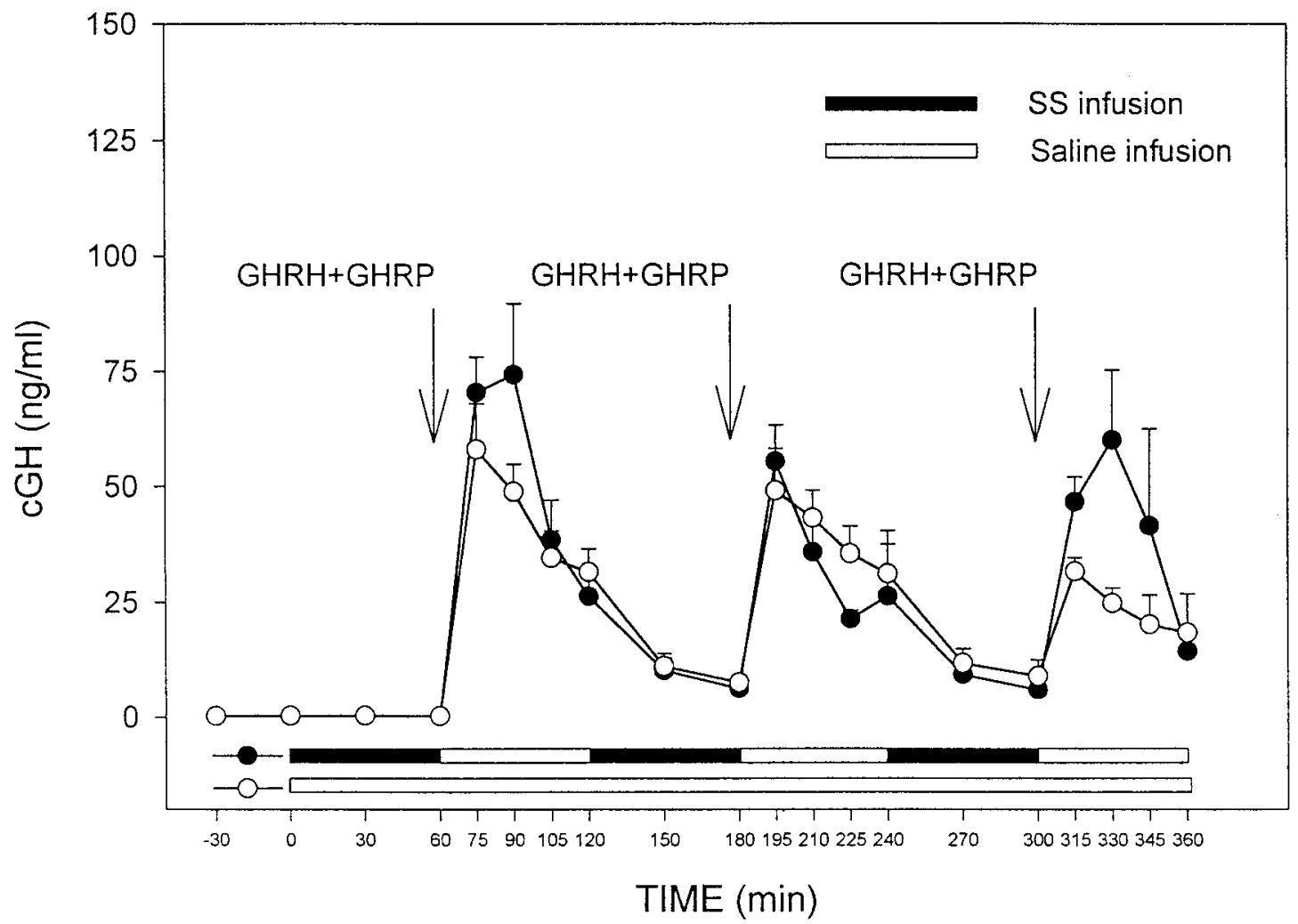

Figure 4 Plasma GH concentration profiles (means \pm S.E.M., $\mathrm{ng} / \mathrm{ml}$ ) from 5 dogs administered three consecutive boli of $\mathrm{GHRH}(2 \mu \mathrm{g} / \mathrm{kg}$ ev) plus EP92632 (GHRP; $125 \mu \mathrm{g} / \mathrm{kg}$ iv).

vs $\mathrm{AUC}_{180-240 ;}$ SALI, $P=\mathrm{NS}$ ). SSIW at the time of the first EP92632 bolus injection strikingly enhanced the $\mathrm{GH}$ release elicited by the peptide $\left(\mathrm{AUC}_{60-120}\right.$; SSIW $=1790.5 \pm 162.7 \mathrm{ng} / \mathrm{ml} / \mathrm{min}$ vs $\mathrm{AUC}_{60-120 ;}$ SALI, $P<0.01)$. This pattern was also present, although to a lesser extent, with the second and third SSIWs $\quad\left(\right.$ AUC $_{180-240 ;}$ SSIW $=736.4 \pm 118.7 \mathrm{ng} / \mathrm{ml} / \mathrm{min}$ vs $\mathrm{AUC}_{180-240 ;}$ sALI, $\mathrm{P}<0.01 ; \mathrm{AUC}_{300-360 ;}$ sSIW $=$ $890.5 \pm 70.8 \mathrm{ng} / \mathrm{ml} / \mathrm{min}$ vs $\mathrm{AUC}_{300-360 ;}$ sALI, $P<$ 0.05) (Fig. 3, Table 1).

Combined administration of GHRH and EP92632 during SALI induced a synergistic effect on GH release, which overrode any effect of previous GHRH or EP92632 results $\left(\mathrm{AUC}_{60-120}\right.$; SALI $=2363.3 \pm 339.8$ $\mathrm{ng} / \mathrm{ml} / \mathrm{min}$ vs $\mathrm{AUC}_{60-120 \text {; SALI }}$ after saline, $P<0.01$; vs $\mathrm{AUC}_{60-120 ;}$ SALI after GHRH, $P<0.01$; vs $\mathrm{AUC}_{60-120}$; SALI after EP92632, $P<0.01)$. A progressive reduction in the extent of the $\mathrm{GH}$ response was present after the second and the third GHRH plus EP92632 bolus injections $\left(\mathrm{AUC}_{180-240 ;}\right.$ SALI $=2210.9 \pm 151.6 \mathrm{ng} / \mathrm{ml} /$ $\min$ vs $\mathrm{AUC}_{60-120 ;}$ SALI, $\quad P<0.01 ; \mathrm{AUC}_{300-360}$; SALI $=1353.8 \pm 248.4 \mathrm{ng} / \mathrm{ml} / \mathrm{min}$ vs $\mathrm{AUC}_{180-240 ;}$ SALI, $P<0.01)$.

The GH response to the first co-administration of the peptides was slightly increased after SSIW $\left(\mathrm{AUC}_{60-120}\right.$; SSIW $=2946.0 \pm 280.0 \mathrm{ng} / \mathrm{ml} / \mathrm{min}$ vs $\mathrm{AUC}_{60-120}$ : SALI, $P<0.05)$. In contrast, SSIW did not affect the GH rise evoked by the second bolus of GHRH plus EP92632 $\left(\mathrm{AUC}_{180-240 ;}\right.$ SSIW $=1934.3 \pm 303.8 \mathrm{ng} / \mathrm{ml} / \mathrm{min} \quad$ vs AUC $_{180-240 ;}$ SALI, $P=$ NS), and a rather similar pattern was present after SSIW in the third GH response, although the difference compared with the results elicited during SALI was significant $\left(\mathrm{AUC}_{300-360 ;}\right.$ ssiw $=2378.1 \pm$ $534.0 \mathrm{ng} / \mathrm{ml} / \mathrm{min}$ vs $\mathrm{AUC}_{300-360 \text {; SALI }}, P<0.01$ ) (Fig. 4; Table 1).

No adverse side-effects were recorded during or after SS infusion or administration of GH secretagogs either alone or combined.

\section{Discussion}

An optimal pulsatile $\mathrm{GH}$ release requires the combination of pulsatile GHRH stimulation and a cyclic variation in the SS tone both to prevent leakage of pituitary $\mathrm{GH}$ and to maximize the $\mathrm{GH}$ pulse that can be secreted in a short time following the next GHRH pulse (28). Reportedly, SSIW either in animals (24-27) or humans (28-30) elicits a rebound GH rise which has been referred to a hypothalamic component, i.e. disinhibition of GHRH neuronal function $(2,4,24$, $26,27,29)$.

In our study, the repetition of SSIW was followed by equivalent GH secretory episodes, suggesting that this mechanism could have activated a physiological 
mechanism which mimics that which normally controls $\mathrm{GH}$ pulse generation $(28,36)$. Exposure to three SS cycles of 1 -h duration presumably simulates endogenous SS secretion and allows sufficient GHRH to be synthesized at the hypothalamic level. Release of the same GHRH quantum induced by SSIW would be responsible for the uniform episodes of $\mathrm{GH}$ secretion detected at each SSIW cycle.

Based on the observation that the second and third GHRH boli delivered during SALI failed to elicit any sound GH rise (Fig. 2) - as already reported in in vitro $(37,38)$ and in vivo $(39,40)$ studies - the uniformity of $\mathrm{GH}$ release at each SSIW cycle appears to be a very interesting finding.

For GHRH, it has been argued that pituitary desensitization to repeated boli is responsible for the state of refractoriness (41), although depletion of a readily releasable pool sensitive to GHRH cannot be excluded (42). A more likely explanation, however, rests on the induction of a GH negative auto-feedback elicited by the GH rise following the first GHRH bolus. The increase in plasma GH concentrations would enhance hypothalamic SS tone (and probably reduce concomitantly the activity of GHRH-secreting neurons) (43-47), thus blunting the subsequent responsiveness to GHRH. Supporting this proposition is the finding that a cholinergic drug, pyridostigmine, which inhibits SS release (48), given before the second GHRH bolus, reinstates $\mathrm{GH}$ responsiveness to the peptide in humans $(49,50)$.

In the SSIW experiments in which GHRH was administered at the end of the first cycle, the $\mathrm{GH}$ rebound was greater than in the saline-GHRH experiments. This was related, presumably, to the activation of GHRH pituitary 'spare' receptors (28) rather than to the release of a maximal quantum of endogenous GHRH following SSIW. At the following SSIW cycles, the GH responses to GHRH were blunted and similar to those of the saline-GHRH experiments.

EP92632, a synthetic GHRP heptapeptide, exhibited a GH-releasing activity which was greater than that of GHRH; when combined with GHRH a striking synergistic effect was induced, the $\mathrm{GH}$ release following administration of both compounds being higher than the arithmetic sum of the $\mathrm{GH}$ rises induced by each compound given separately. Paradoxically, although there were unequivocal $\mathrm{GH}$ rises after each bolus of EP92632 alone, the GH-releasing effects of the second and third EP92632 boli were merely blunted, whereas the smaller $\mathrm{GH}$ response to $\mathrm{GHRH}$ had been nearly abolished (see above). Also, the GH responses to combined administration of EP92632 and GHRH were only slightly attenuated by the previous bolus.

Taken together, these data indicate that EP92632 probably counteracted the negative GH auto-feedback which activates somatostatinergic neurons, a proposition in keeping with the antagonistic action of GHRP on SS function $(11,51,52)$.
In addition, inferential evidence has also been presented that GHRPs may play a role in SS action, functioning as SS antagonists at the pituitary level (53). For instance, in conscious rats, continuous subthreshold infusion of GHRP-6, a GHRP compound, together with repeated injections of GHRH, induced GH responses that were uniform and greater in magnitude than those of rats given GHRH alone. Interestingly, interpeak serum GH concentrations were high between repeated GHRH boli, suggesting that GHRP-6 had reduced SS inhibitory influences on the pituitary (52). Also, under our experimental conditions an antagonistic action of EP92632 on SS function at the pituitary level cannot be ruled out.

Regardless of the fact that the validity of these propositions needs to be verified, and in contrast with the scarce reproducibility of the GHRH challenge (54, 55 ), our study suggests that the repeatability of the $\mathrm{GH}$ response to multiple boli of a GHRP may be exploited clinically in GH hyposecretory states.

The most peculiar finding of this study was the clearcut enhancement of the EP92632-stimulated GH response present after each SSIW cycle. This fact, in view of the known functional interactions between GHRPs and GHRH, reinforces the proposition that SSIW disinhibits hypothalamic GHRH neurons, allowing a synergy of the exogenously administered GHRP with endogenously released GHRH $(31,56)$. Since, reportedly, GHRPs promptly stimulate hypothalamic GHRH neurons $(11,57,58)$, the biological effects of the endogenous GHRH release following SSIW could be further magnified.

In this context, it is noteworthy that co-administration of GHRH and EP92632 at the time of interruption of SS infusion barely increased the extent of the GH response over that following the combined administration of GHRP and GHRH during SALI, which would indicate that endogenous GHRH release triggered by SSIW was nearly maximal.

Recently, Cappa et al. (30) have demonstrated that SSIW elicits a significant $\mathrm{GH}$ rise in normal control children (NC), but not in $\mathrm{GH}$ deficient children, regardless of the underlying etiology, i.e. GH deficiency (GHD) or GH neurosecretory dysfunction (GHND). This approach allowed complete discrimination of $\mathrm{NC}$ from GHD or GHND, but not of GHD from GHND children. Also Popovic et al. (59) have recently shown that combined administration of GHRH plus GHRP-6 only distinguishes healthy from GHD (and GHND) adults.

In patients with hypothalamic-pituitary disconnection, hexarelin, a potent GHRP in both animals and men $(9,60-64)$, failed to elicit a GH response, whereas it stimulated GH secretion in patients with GHND, with a lower inter- and intra-individual variability than that occurring with GHRH $(65,66)$.

In view of the results of our study, one wonders whether combined SSIW and GHRP injection may be a valid tool to distinguish GHD of hypothalamic origin 
from a combined hypothalamic/pituitary or a primary pituitary impairment. In fact, in GHD of hypothalamic origin SSIW plus GHRP bolus would induce a GH release intermediate between the one elicited in normal control children and that of children with hypothalamic/pituitary or primary pituitary impairment. Granted that the synergy of SSIW-exogenous GHRP is defective in hypothalamic subjects, GHRP still has the potential to stimulate specific GHRP receptors (13), to inhibit SS function $(7,23)$ and to act directly at the pituitary level $(14,15)$. GH release following SSIW and GHRP should be minimal or even absent in subjects with combined hypothalamic/pituitary or primary pituitary impairment.

If the findings of our study could be extrapolated to humans, the GHRP challenge after SSIW, because of its effectiveness and safety, procedural simplicity and economy, might be a useful diagnostic tool in GHdependent growth disorders.

\section{Acknowledgements}

We are grateful to Dr M Pitaro, Serono, Rome, Italy for providing us with GHRH.

\section{References}

1 Tannenbaum GS \& Ling N. The interrelationship of growth hormone $(\mathrm{GH})$-releasing factor and somatostatin in generation of the ultradian rhythm of GH secretion. Endocrinology 1984115 1952-1957.

2 Plotsky PM \& Vale W. Patterns of growth hormone-releasing factor and somatostatin secretion into the hypophysial-portal circulation of the rat. Science $1985230461-463$.

3 Clark RG \& Robinson IC. Growth hormone responses to multiple injections of a fragment of human growth hormone-releasing factor in conscious male and female rats. Journal of Endocrinology $1985106281-289$.

4 Katakami H, Downs TR \& Frohman LA. Inhibitory effect of hypothalamic medial preoptic area somatostatin on growth hormone-releasing factor in the rat. Endocrinology $1988 \mathbf{1 2 3}$ 1103-1109.

5 Sato M, Chihara K, Kita T, Kashio Y, Okimura Y, Kitajima N et al. Physiological role of somatostatin-mediated autofeedback regulation for growth hormone: importance of growth hormone in triggering somatostatin release during a trough period of pulsatile growth hormone release in conscious male rats. Neuroendocrinology 198950 139-151.

6 Muller EE, Locatelli V \& Cocchi D. Neuroendocrine control of growth hormone secretion. Physiological Reviews 199979511 607.

7 Bowers CY, Sartor AO, Reynolds GA \& Badger TM. On the actions of the growth hormone-releasing hexapeptide, GHRP. Endocrinology 1991128 2027-2035.

8 Bowers CY, Reynolds GA, Durham D, Barrera CM, Pezzoli SS \& Thorner MO. Growth hormone (GH)-releasing peptide stimulates $\mathrm{GH}$ release in normal men and acts synergistically with GHreleasing hormone. Journal of Clinical Endocrinology and Metabolism 199070 975-982.

9 Cella SG, Locatelli V, Poratelli M, De Gennaro Colonna V, Imbimbo BP, Deghenghi $\mathrm{R}$ et al. Hexarelin, a potent GHRP analogue: interactions with GHRH and clonidine in young and aged dogs. Peptides $19951681-86$.
10 Bowers CY. GH releasing peptides - structure and kinetics. Journal of Pediatric Endocrinology 19936 21-31.

11 Dickson SL, Viltart O, Bailey AR \& Leng G. Attenuation of the growth hormone secretagogue induction of Fos protein in the rat arcuate nucleus by central somatostatin action. Neuroendocrinology 199766 188-194.

12 Locatelli V \& Torsello A. Growth hormone secretagogues: focus on the growth hormone-releasing peptides. Pharmacological Research 199736 415-423.

13 Codd EE, Shu AY \& Walker RF. Binding of a growth hormone releasing hexapeptide to specific hypothalamic and pituitary binding sites. Neuropharmacology 198928 1139-1144.

14 Sethumadhavan K, Veeraragavan K \& Bowers CY. Demonstration and characterization of the specific binding of growth hormonereleasing peptide to rat anterior pituitary and hypothalamic membranes. Biochemical and Biophysical Research Communications 1991178 31-37.

15 Howard AD, Feighner SD, Cully DF, Arena JP, Liberator PA, Rosenblum CI et al. A receptor in pituitary and hypothalamus that functions in growth hormone release. Science 1996273 974-977.

16 Smith RG, Palyha OC, Feighner SD, Tan CP, McKee KK, Hreniuk DL et al. Growth hormone releasing substances: types and their receptors. Hormone Research 199951 (Suppl 3) 1-8.

17 Hosoda H, Kojima M, Matsuo H \& Kangawa K. Purification and characterization of rat des-Gln14-Ghrelin, a second endogenous ligand for the growth hormone secretagogue receptor. Journal of Biological Chemistry 2000275 1995-2000.

18 Dieguez C \& Casanueva FF. Ghrelin: a step forward in the understanding of somatotroph cell function and growth regulation. European Journal of Endocrinology $2000142413-417$.

19 Kojima M, Hosoda H, Date Y, Nakazato M, Matsuo H \& Kangawa K. Ghrelin is a growth-hormone-releasing acylated peptide from stomach. Nature $1999 \mathbf{4 0 2} 656-660$.

20 Fairhall KM, Mynett A \& Robinson IC. Central effects of growth hormone-releasing hexapeptide (GHRP-6) on growth hormone release are inhibited by central somatostatin action. Journal of Endocrinology $1995 \mathbf{1 4 4}$ 555-560.

21 Bowers CY, Momany FA, Reynolds GA \& Hong A. On the in vitro and in vivo activity of a new synthetic hexapeptide that acts on the pituitary to specifically release growth hormone. Endocrinology $19841141537-1545$.

22 Blake AD \& Smith RG. Desensitization studies using perifused rat pituitary cells show that growth hormone-releasing hormone and His-D-Trp-Ala-Trp-D-Phe-Lys- $\mathrm{NH}_{2}$ stimulate growth hormone release through distinct receptor sites. Journal of Endocrinology $199112911-19$.

23 Deghenghi R, Locatelli V, Papotti M, Ghigo E \& Muccioli G. Two birds with one stone - the GHRP receptor as a new receptor for somatostatin octapeptide analogs and a new paradigm for how GHRPs work. Third International Symposium on Growth Hormone Secretagogues, Keystone Resort, Colorado, 2000.

24 Miki N, Ono M \& Shizume K. Withdrawal of endogenous somatostatin induces secretion of growth hormone-releasing factor in rats. Journal of Endocrinology $1988117245-252$.

25 Sugihara H, Minami S \& Wakabayashi I. Post-somatostatin rebound secretion of growth hormone is dependent on growth hormone-releasing factor in unrestrained female rats. Journal of Endocrinology 1989122 583-591.

26 Robinson IC, Jeffery S \& Clark RG. Somatostatin and its physiological significance in regulating the episodic secretion of growth hormone in the rat. Acta Paediatrica Scandinavica Supplement $199036787-92$.

27 Cella SG, Luceri M, Cattaneo L, Torsello A \& Muller EE. Somatostatin withdrawal as generator of pulsatile $\mathrm{GH}$ release in the dog: a possible tool to evaluate the endogenous GHRH tone? Neuroendocrinology 199663 481-488.

28 Hindmarsh PC, Brain CE, Robinson IC, Matthews DR \& Brook CG. The interaction of growth hormone releasing hormone and somatostatin in the generation of a $\mathrm{GH}$ pulse in man. Clinical Endocrinology 199135 353-360. 
29 degli Uberti EC, Ambrosio MR, Cella SG, Margutti AR, Trasforini G, Rigamonti AE et al. Defective hypothalamic growth hormone (GH)-releasing hormone activity may contribute to declining GH secretion with age in man. Journal of Clinical Endocrinology and Metabolism 199782 2885-2888.

30 Cappa M, Rigamonti AE, Bizzarri C, Porzio O, Civolani P, Cella SG et al. Somatostatin infusion withdrawal: studies in normal children and in children with growth hormone deficiency. Journal of Clinical Endocrinology and Metabolism 199984 4426-4430.

31 Massoud AF, Hindmarsh PC \& Brook CG. Interaction of the growth hormone releasing peptide hexarelin with somatostatin. Clinical Endocrinology 199747 537-547.

32 Muller EE. Neural control of somatotropic function. Physiological Reviews 198767 962-1053.

33 French MB, Vaitkus P, Cukerman E, Sirek A \& Sirek OV. Secretory pattern of canine growth hormone. American Journal of Physiology 1987252 E268-E272.

34 Cowan JS, Gaul P, Moor BC \& Kraicer J. Secretory bursts of growth hormone secretion in the dog may be initiated by somatostatin withdrawal. Canadian Journal of Physiology and Pharmacology 198462 199-207.

35 Holl RW, Hartman ML, Veldhuis JD, Taylor WM \& Thorner MO. Thirty-second sampling of plasma growth hormone in man: correlation with sleep stages. Journal of Clinical Endocrinology and Metabolism $1991 \mathbf{7 2} 854-861$.

36 Stachura ME, Tyler JM \& Kent PG. Pituitary immediate release pools of growth hormone and prolactin are preferentially refilled by new rather than stored hormone. Endocrinology 1989125 444-449.

37 Kraicer J, Cowan JS, Sheppard MS, Lussier B \& Moor BC. Effect of somatostatin withdrawal and growth hormone $(\mathrm{GH})$-releasing factor on GH release in vitro: amount available for release after disinhibition. Endocrinology 1986119 2047-2051.

38 Stachura ME, Tyler JM \& Farmer PK. Combined effects of human growth hormone $(\mathrm{GH})$-releasing factor-44 (GRF) and somatostatin (SRIF) on post-SRIF rebound release of GH and prolactin: a model for GRF-SRIF modulation of secretion. Endocrinology 1988 123 1476-1482.

39 Losa M, Muller OA, Sobieszczyk S \& von Werder K. Interaction between growth hormone releasing factor (GRF) and somatostatin analogue (SMS 201-995) in normal subjects. Clinical Endocrinology 198523 715-720.

40 Suri D, Hindmarsh PC, Matthews DR, Brain CE \& Brook CG. The pituitary gland is capable of responding to two successive doses of growth hormone releasing hormone (GHRH). Clinical Endocrinology 199134 13-17.

41 Bilezikjian LM, Seifert H \& Vale W. Desensitization to growth hormone-releasing factor (GRF) is associated with down-regulation of GRF-binding sites. Endocrinology 1986118 2045-2052.

42 Richardson SB \& Twente S. Evidence that diminished pituitary responsivity to GHRF is secondary to intracellular GH pool depletion. American Journal of Physiology 1988254 E358-E364.

43 Aguila MC \& McCann SM. Stimulation of somatostatin release in vitro by synthetic human growth hormone-releasing factor by a nondopaminergic mechanism. Endocrinology 1985117762 765.

44 Devesa J, Lima L, Lois N, Fraga C, Lechuga MJ, Arce V et al. Reasons for the variability in growth hormone $(\mathrm{GH})$ responses to GHRH challenge: the endogenous hypothalamic-somatotroph rhythm (HSR). Clinical Endocrinology 198930 367-377.

45 Kelijman M \& Frohman LA. Impaired inhibitory effects of somatostatin on growth hormone $(\mathrm{GH})$-releasing hormone stimulation of $\mathrm{GH}$ secretion after short term infusion. Journal of Clinical Endocrinology and Metabolism 199071 157-163.

46 Suri D, Hindmarsh PC, Brain CE, Pringle PJ \& Brook CG. The interaction between clonidine and growth hormone releasing hormone in the stimulation of growth hormone secretion in man. Clinical Endocrinology 1990 33 399-406.

47 Arvat E, Di Vito L, Gianotti L, Ramunni J, Boghen MF, Deghenghi $\mathrm{R}$ et al. Mechanisms underlying the negative growth hormone (GH) autofeedback on the GH-releasing effect of hexarelin in man. Metabolism 199746 83-88.

48 Wehrenberg WB, Wiviott SD, Voltz DM \& Giustina A. Pyridostigmine-mediated growth hormone release: evidence for somatostatin involvement. Endocrinology 1992130 1445-1450.

49 Ghigo E, Goffi S, Mazza E, Arvat E, Procopio M, Bellone J et al. Repeated GH-releasing hormone administration unravels different GH secretory patterns in normal adults and children. Acta Endocrinologica $1989 \mathbf{1 2 0} 598-601$.

50 Martina V, Bruno G, Tagliabue M, Maccario M, Bertaina S, Zumpano E et al. Repeated administration of growth hormonereleasing hormone with or without previous administration of pyridostigmine in insulin-dependent diabetes mellitus. Hormone and Metabolic Research 199729 180-183.

51 Dickson SL \& Luckman SM. Induction of c-fos messenger ribonucleic acid in neuropeptide $\mathrm{Y}$ and growth hormone (GH)releasing factor neurons in the rat arcuate nucleus following systemic injection of the $\mathrm{GH}$ secretagogue, GH-releasing peptide-6. Endocrinology 1997138 771-777.

52 Fairhall KM, Mynett A, Smith RG \& Robinson IC. Consistent GH responses to repeated injection of GH-releasing hexapeptide (GHRP-6) and the non-peptide GH secretagogue, L-692,585. Journal of Endocrinology 1995145 417-426.

53 Roh SG, He ML, Matsunaga N. Hidaka S \& Hidari H. Mechanisms of action of growth hormone-releasing peptide- 2 in bovine pituitary cells. Journal of Animal Science $1997 \mathbf{7 5}$ 2744-2748.

54 Hoeck HC, Jakobsen PE, Vestergaard P, Falhof J \& Laurberg P. Differences in reproducibility and peak growth hormone responses to repeated testing with various stimulators in healthy adults. Growth Hormone and IGF Research 19999 18-24.

55 Ghigo E, Bellone J, Aimaretti G, Bellone S, Loche S, Cappa M et al. Reliability of provocative tests to assess growth hormone secretory status. Study in 472 normally growing children. Journal of Clinical Endocrinology and Metabolism 199681 3323-3327.

56 Ghigo E, Arvat E, Broglio F, Giordano R, Gianotti L, Muccioli G et al. Endocrine and non-endocrine activities of growth hormone secretagogues in humans. Hormone Research 199951 (Suppl 3) $9-15$.

57 Kamegai J, Hasegawa O, Minami S, Sugihara H \& Wakabayashi I. The growth hormone-releasing peptide KP-102 induces c-fos expression in the arcuate nucleus. Brain Research. Molecular Brain Research 199639 153-159.

58 Sirinathsinghji DJ, Chen HY, Hopkins R, Trumbauer M, Heavens R, Rigby $\mathrm{M}$ et al. Induction of $\mathrm{c}$-fos mRNA in the arcuate nucleus of normal and mutant growth hormone-deficient mice by a synthetic non-peptidyl growth hormone secretagogue. Neuroreport 19956 1989-1992.

59 Popovic V, Leal A, Micic D, Koppeschaar HP, Torres E, Paramo C et al. GH-releasing hormone and GH-releasing peptide- 6 for diagnostic testing in GH-deficient adults. Lancet $2000 \mathbf{3 5 6}$ $1137-1142$.

60 Torsello A, Grilli R, Luoni M, Guidi M, Ghigo MC, Wehrenberg WB et al. Mechanism of action of hexarelin. I. Growth hormonereleasing activity in the rat. European Journal of Endocrinology 1996135 481-488.

61 Cella SG, Cerri CG, Daniel S, Sibilia V, Rigamonti A, Cattaneo L et al. Sixteen weeks of hexarelin therapy in aged dogs: effects on the somatotropic axis, muscle morphology, and bone metabolism. Journals of Gerontology. Series A, Biological Sciences and Medical Sciences 199651 B439-B447.

62 Arvat E, Gianotti L, Di Vito L, Imbimbo BP, Lenaerts V, Deghenghi $\mathrm{R}$ et al. Modulation of growth hormone-releasing activity of hexarelin in man. Neuroendocrinology $19956151-$ 56.

63 Camanni F, Ghigo E \& Arvat E. Growth hormone-releasing peptides and their analogs. Frontiers in Neuroendocrinology 1998 $1947-72$

64 Rahim A, O'Neill PA \& Shalet SM. Growth hormone status during long-term hexarelin therapy. Journal of Clinical Endocrinology and Metabolism 199883 1644-1649. 
65 Loche S, Colao A, Cappa M, Bellone J, Aimaretti G, Farello G et al. The growth hormone response to hexarelin in children: reproducibility and effect of sex steroids. Journal of Clinical Endocrinology and Metabolism 199782 861-864.

66 Maghnie M, Spica-Russotto V, Cappa M, Autelli M, Tinelli C, Civolani $\mathrm{P}$ et al. The growth hormone response to hexarelin in patients with different hypothalamic-pituitary abnormalities.
Journal of Clinical Endocrinology and Metabolism $1998 \mathbf{8 3} 3886-$ 3889 .

Received 5 March 2001

Accepted 5 June 2001 